\title{
Therapeutic Trial of an Endothelin Receptor Agonist for the Highly Pathogenic Avian Influenza A/H5N1 Virus Infection in Chicks
}

\author{
Kazuhide Adachi' ${ }^{1}$, Retno Damajanti Soejoedono², Ekowati Handharyani2, Marie Inai', \\ Yasuhiro Tsukamoto ${ }^{{ }^{*}}$ \\ ${ }^{1}$ Department of Animal Hygiene, Graduate School of Environmental \& Biological Sciences, Kyoto Prefecture \\ University, Kyoto, Japan \\ ${ }^{2}$ Faculty of Veterinary Medicine, Bogor Agriculture University, Bogor, Indonesia \\ Email: ${ }^{*}$ tsuka@kpu.ac.jp
}

Received 29 August 2014; revised 14 October 2014; accepted 29 October 2014

Copyright (C) 2014 by authors and Scientific Research Publishing Inc.

This work is licensed under the Creative Commons Attribution International License (CC BY). http://creativecommons.org/licenses/by/4.0/

(c) (i) Open Access

\section{Abstract}

The rapid spread of the highly pathogenic A/H5N1 avian influenza virus among domestic birds and its transmission to humans has induced world-wide fears of a new influenza pandemic. A/H5N1 has infected over 300 people since 1997, and has shown a mortality rate of over $50 \%$. The high mortality in human cases is thought to be enhanced by the excessive secretion of various endogenous factors, including cytokines and interleukins, stimulated by viral infections. Chickens infected with A/H5N1 viruses experience sudden death without showing severe clinical symptoms or inflammation. However, severe hemorrhage and congestion are seen in various tissues in sporadic chicken cases of $\mathrm{A} / \mathrm{H} 5 \mathrm{~N} 1$-infections, especially in the pulmonary tissues, thus indicating that there is ischemia due to vascular abnormalities. Our previous studies have focused on the expression pattern of endothelin-1, which modulates the vascular tone via endothelin receptors. An Indonesian sporadic strain of A/H5N1 virus was intranasally administered to 10-day-old chicks, and the expression of endothelin was examined in the infected birds. All birds died within five days of inoculation, and had moderate inflammation accompanied by severe hemorrhage and congestion in the lungs. Immunohistochemical studies showed enhanced expression of endothelin-1 in the infected lungs. In addition, the real-time PCR analyses revealed that endothelin-1 and endothelin receptor A mRNA were significantly elevated in the birds with A/H5N1 infections. Subsequently, H5N1-infected birds were inoculated with bosentan hydrate, a competitive antagonist of endothelin receptors. Interestingly, the mortality rate of the infected birds was dramatically decreased in a dose-dependent manner by the administration of bosentan hydrate. The pathological lesions, including congestion and hemorrhage in the pulmonary tissues, were clearly inhibited. These find-

\footnotetext{
${ }^{*}$ Corresponding author.
}

How to cite this paper: Adachi, K., Soejoedono, R.D., Handharyani, E., Inai, M. and Tsukamoto, Y. (2014) Therapeutic Trial of an Endothelin Receptor Agonist for the Highly Pathogenic Avian Influenza A/H5N1 Virus Infection in Chicks. Health, 6, 2553-2561. http://dx.doi.org/10.4236/health.2014.619294 
ings are promising, and suggest that endothelin receptor antagonists are a potential treatment for the highly pathogenic avian flu.

\title{
Keywords
}

\author{
Avian Influenza Virus, A/H5N1, Endothelin Receptor, Chicken
}

\section{Introduction}

Influenza infection is recognized as a zoonotic disease, and the viruses are divided into three types; A, B and C. The influenza A viruses are further classified into subtypes on the basis of their antigenic properties, including hemagglutinin (HA) and neuraminidase (NA), on the viral particle [1]. A-type viruses are maintained in wild water birds as a reservoir, but show low pathogenicity in these birds. However, the virulence is much higher in other avian species, including chickens and Japanese quails [2]. The A/H5N1 virus was transmitted to humans in Hong Kong in 1997, and then spread into Africa, Indonesia, Vietnam and Egypt via domestic and wild birds [3]. Over 300 people in Indonesia have been infected with A/H5N1, resulting in a mortality rate of over 50\% [4] [5]. This virus is an imminent threat to humans, the poultry industry and potentially wild birds, and there is a high risk of a worldwide pandemic, which could cause considerable mortality and economic disruption [6]-[8].

The A/H5N1 virus attaches to receptors on the cell surface, enters the cytoplasm by endocytosis, replicates using host enzymes and nucleotides, and a huge number of virions are subsequently produced by the host cells. These viruses spread systematically via the bloodstream and infect various organs expressing the viral receptors [7] [9]-[11]. Then, various respiratory, digestive and nervous system symptoms appear, and the resultant multiple organ failure (MOF) finally leads to death. A/H5N1 infection causes the hyper-expression of various cytokines, leading to the so-called "cytokine storm", in comparison to the seasonal influenza virus A/H1N1 or A/ H3N2 infections [5] [9] [12] [13]. Studies using transgenic mice lacking major cytokines, including tumor necrosis factor (TNF)- $\alpha$, interleukin (IL)-6 and CC chemokine ligand 2 (CCL2), showed no altered pathogenesis after lethal A/H5N1 influenza virus infection [14]. The lack of only one cytokine has no effect on A/H5N1 infections, because the cytokine storm is a multiple cytokine event [15]. Accordingly, the development of acute respiratory distress syndrome, MOF and encephalopathy in human cases of A/H5N1 are thought to be induced by this cytokine storm.

Endothelins are vasoconstrictor peptides that contribute to various physiological functions in a variety of tissues, and belong to a family of three endogenous proteins; endothelin-1, endothelin-2 and endothelin-3 [16] [17]. Endothelin-1, a 23-residue peptide, is the most common endothelin produced by endothelial cells. Abnormal secretion of endothelin-1 was shown to increase pulmonary hypertension in the rat lungs by inducing vasoconstriction due to the induced contraction of pulmonary arteries by the contraction of the smooth muscles [18]-[20]. Endothelin-1 modulates the vascular tone via interactions with endothelin receptors type A and B [21]. Both receptors are expressed in vascular smooth muscle cells in pulmonary blood vessels, as well as in nerve trunks and submucosal glands. Endothelin receptor A on the vascular smooth muscle cells is responsible for the vasoconstrictor effects of endothelin-1, whereas endothelin receptor B on the endothelial cells mediates vasodilatation. The expression of endothelin-1 increases in the airways of mice infected with $\mathrm{A} / \mathrm{H} 1 \mathrm{~N} 1$, and the distribution of endothelin-positive cells is co-localized with the inflammatory reactions associated with viral infection [22]. However, the effects and contributions of endothelin-1 to virus-induced pulmonary diseases remain to be clarified.

Chickens suffering from avian flu caused by A/H5N1 viruses normally experience sudden death within seven days of infection, without showing any severe systemic degenerative or inflammatory response [2]. Sporadic chicken cases of A/H5N1-infections show severe hemorrhage, and edema and congestion have been seen in various tissues, especially pulmonary tissues, thus indicating that there is ischemia due to vascular abnormalities that are similar to the findings of human acute respiratory distress syndrome.

This study focused on the expression pattern of endothelin that modulated the vascular tone via endothelin receptor type A (ETA) to elucidate the pathogenicity of A/H5N1 infections. The aim of this study is to confirm whether the inhibition of endothelin function can rescue animals from sudden death due to A/H5N1 infections. 


\section{Materials and Methods}

\subsection{A Sporadic Strain of High Pathological Avian Influenza Virus A/H5N1}

A sporadic strain of A/H5N1 virus, A/Bogor 2/IPB/H5N1, was employed in this study. This strain was highly pathologic in domestic chickens by an experimental infection [23] [24]. For the viral titration, Madin-Darby canine kidney (MDCK) cells were grown in Dulbecco’s minimal essential medium (DMEM) with 10\% fetal bovine serum (FBS) and anti-mycosis agents and antibiotics at $37^{\circ} \mathrm{C}$ in $5 \% \mathrm{CO}_{2}$. The cells were re-seeded onto each well of a 96-well microtiter plate and grown to semi-confluence. After removal of the culture media and sufficient washing with phosphate-buffered saline (PBS), serial dilutions of viral fluids were adsorbed onto MDCK monolayers in each well for $1 \mathrm{hr}$ at $35^{\circ} \mathrm{C}$, and then incubated in GIT media containing a low concentration of trypsin at $35^{\circ} \mathrm{C}$. The cultures were inspected for cytopathic effects (CPE) five days post-incubation; the viral infective titer was calculated and scored as the $50 \%$ tissue culture infective dose $\left(\mathrm{TCID}_{50}\right)$ [25].

\subsection{Experimental Challenge of Chickens with $\mathrm{A} / \mathrm{H} 5 \mathrm{~N} 1$ and Bosentan Hydrate Administration}

Newly-hatched broiler chicks were housed under controlled conditions in a BSL3 laboratory and received food and water ad libitum. When they were 10 days old, the birds were inoculated intranasally with A/H5N1 virus $\left(10^{5} \mathrm{TCID}_{50} / \mathrm{ml}\right)$ [23]. Some chicks were injected intramuscularly with $0.2 \mathrm{ml}$ of bosentan hydrate 2 hrs after infection $(0,8$ or $16 \mathrm{mg} / \mathrm{mL})$ [26] [27], and all birds were housed for another five days. A higher volume of drug $(62.5 \mathrm{mg} / \mathrm{mL}$ ) was administrated to non-infected (normal) birds to confirm the safety of the treatment.

At least five birds were prepared for each volume of the drugs. Five days after inoculation, the dead birds were counted and the survival rate was scored in each group (survival birds/all birds examined). The survivors were sacrificed with pentobarbital sodium solution, the lungs were removed and the expression of endothelin and its receptors was analyzed by PCR. The lung samples were also immersed in 10\% neutral buffered formalin for further histopathology and immunohistochemistry studies. For the histopathology studies, the paraffin sections were cut at 3- $\mu \mathrm{m}$ with a microtome and stained with hematoxylin and eosin $(\mathrm{H} \& \mathrm{E})$ per routine procedures, and then were observed under a light microscope. All of the animal experiments were performed in accordance with the guidelines for studies with laboratory animals of the Kyoto Prefectural University Experimental Animal Committee (No. KPU09115).

\subsection{Immunohistochemistry for Viral Antigens}

Tissues were fixed in buffered formalin and washed in PBS. The organs were cut into 5 mm cubes and soaked in $30 \%$ sucrose in PBS overnight. The organ pieces were mounted in a compound, frozen and cut into $5 \mu \mathrm{m}$ sections with a cryostat. The frozen sections were attached to the glass slides and were air-dried at room temperature. After being washed in PBS, the samples were incubated with a mouse monoclonal antibody against influenza A viruses (1:1000) (Serotec) at $4^{\circ} \mathrm{C}$ overnight. The sections were reacted with an FITC-conjugated goat anti-mouse IgG (Invitrogen) at $37^{\circ} \mathrm{C}$ for $1 \mathrm{hr}$ following sufficient washing with PBS. Finally, they were mounted with glycerol, and specific signals for viral antigens were examined under a florescent microscope.

\subsection{Immunohistochemistry for Endothelin-1 Expression}

De-paraffinized sections were incubated with $3 \% \mathrm{H}_{2} \mathrm{O}_{2}$ for 30 min at room temperature in order to inactivate the endogenous peroxidase in the tissues. The sections were washed in PBS, incubated with 10\% goat serum in PBS for $30 \mathrm{~min}$ to reduce the nonspecific antigen-antibody reactions, and then incubated with a mouse monoclonal antibody against endothelin (Phoenix Pharmaceuticals) diluted in PBS (1:1000) at $4^{\circ} \mathrm{C}$ overnight. After sufficient washing in PBS, they were incubated with a biotinylated secondary antibody against mouse IgG (Vector Laboratories) in PBS containing goat serum (1:1000) for $1 \mathrm{hr}$ at 4C. The slides were washed in PBS for 5 min, and incubated for 30 min with biotin-avidin complex solution (Vector Laboratories), diluted and washed in PBS for $5 \mathrm{~min}$. The slides were incubated with fluorescein-conjugated avidin D (Vector Laboratories) in PBS (1:1000) for $1 \mathrm{hr}$ at room temperature, were washed in PBS five times and mounted with cover-glass using glycerol. Finally, the specific fluorescent signal was examined under a fluorescent microscope. 


\subsection{Real-Time RT-PCR Analysis for Endothelin-1 and Endothelin Receptor A}

The endothelin-1 (ET1) and endothelin receptor A (ETA) expression levels were quantified by real-time RTPCR using a StepOne Real Time PCR System (Applied Biosystems). The PCR was performed using the primers for each gene according to the manufacturer's instructions (ET1: 5'-GGACGAGGA GTGCGTGTATT-3', 5'-GCTCCAGCAAGCATCTCTG-3', ETA: 5'-GTGGCCTTTTGGAGATTCTG-3', 5'-GAT TCCGATTCCCTGAACAC-3') [28]. HPRT was used as a control housekeeping gene (5'-TCCAAAGATGGTGAAAGTGG-3', 5'-GCTTCCCCGTCTCACTGAT-3') The final volume was $20 \mu \mathrm{L}$, and contained $10 \mu \mathrm{L}$ of First SYBR Green Master Mix (Applied Biosystems), $0.4 \mu \mathrm{L}$ of each primer, $7.2 \mu \mathrm{L}$ of DPEC and $2 \mu \mathrm{L}$ of each cDNA (RT reaction products). All reactions were subjected to an initial denaturation at $95^{\circ} \mathrm{C}$ for $3 \mathrm{~min}$, followed by 40 cycles of denaturation at $95^{\circ} \mathrm{C}$ for $5 \mathrm{~s}$, annealing at $60^{\circ} \mathrm{C}$ for $15 \mathrm{~s}$ and extension at $72^{\circ} \mathrm{C}$ for $15 \mathrm{~s}$. Melting curve profiles were determined after each reaction (cooling the sample to $68^{\circ} \mathrm{C}$ and heating slowly to $95^{\circ} \mathrm{C}$, with continuous measurement of fluorescence) to confirm the amplification of specific transcripts. The messenger RNA levels were normalized in proportion to the chick HPRT level in each sample. Each experiment was performed for five samples, the scores were averaged and standard errors (SE) were calculated.

\section{Results}

\subsection{Expression of Endothelin-1 and Endothelin Receptor A mRNA in A/H5N1-Infected Chicks}

A strain of highly pathogenic avian influenza virus A/H5N1 was used to infect 10-day-old chicks, and the expression levels of endothelin-1 and endothelin receptor A in the chick lungs were examined five days post-viral infection. The mRNA expression levels of endothelin 1 and endothelin receptor A were analyzed by real-time PCR. The primer sets for each gene amplification were matched to the reactions: the endothelin receptor type was recognized as a single band of 160-bp, and endothelin-1 was found as a 141-bp band in another RT-PCR assay (data not shown). The results were identical to those reported in the literature [28]. Interestingly, a realtime PCR analysis showed that the mRNA level of endothelin-1 was significantly higher in the A/H5N1-infected lungs than in the normal lungs (Figure 1). Furthermore, the levels of endothelin receptor A were also increased in infected birds.

\subsection{Effects of Bosentan Hydrate on the Pathology of A/H5N1-Infected Chickens}

The experimental challenge in living chickens (10 days old) with A/H5N1 caused high lethality among the birds (100\%) within five days post-infection, thus indicating that this virus was categorized as a high virulent type. Of
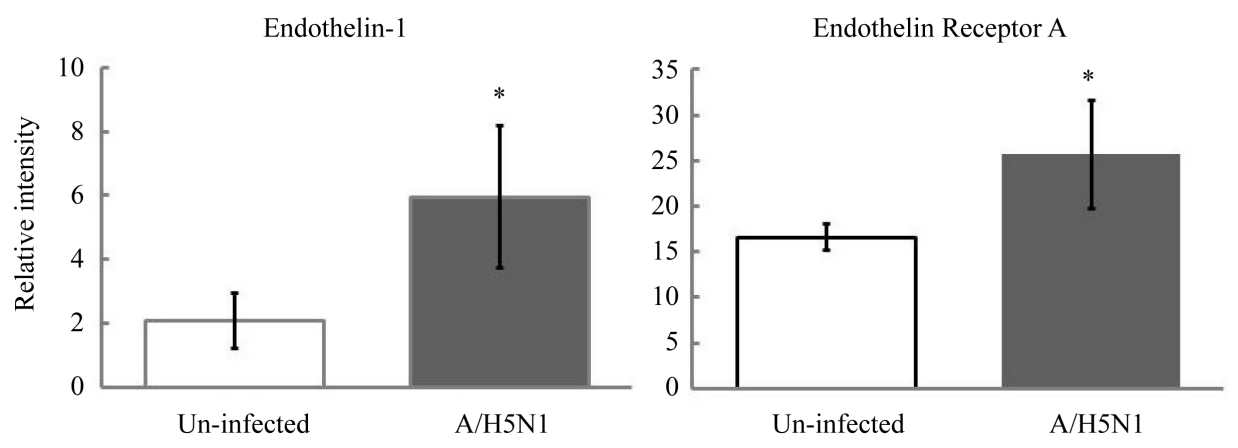

Figure 1. Expression of endothelin-1 and endothelin receptor A mRNA in A/H5N1-infected chick lungs at five days post-infection. The mRNA expression levels of endothelin- 1 and endothelin receptor A were semiquantitatively analyzed by real-time PCR and were normalized to those of the internal control, hypoxanthine phosphoribosyl transferase (HPRT). Examinations were performed in five samples in each experiment, and the values were scored as the means \pm SE. Significant differences between uninfected and the infected lungs at five days post-inoculation are indicated ( $\mathrm{P}<0.05$, compared with data from uninfected birds. Student's $t$-test). Both endothelin-1 and endothelin receptor $A$ were increased in the $\mathrm{A} / \mathrm{H} 5 \mathrm{~N} 1$-infected chick lungs compared with the uninfected normal chick lungs. 
note, all birds showed only slight symptoms, including dehydration and depression, followed by sudden death (Figure 2). The histopathological study of the infected chickens showed the typical avian flu findings of acute inflammation accompanied by heterophilic infiltration, hemorrhage, edema and severe congestion in various organs, mainly in the pulmonary tissues.

The pulmonary sections of infected birds showed slight to moderate inflammation with heterophilic infiltrations in the interstitium and parabronchial cavities. Severe hemorrhage and congestion, accompanied with edema and mucosal exudates, were predominately seen (Figure 3). The inflammation was also seen in the renal tissues. Occasionally, severe micro-hemorrhage and subsequent colliquative necrosis frequently occurred in dead birds, especially in the central nervous system (data not shown).

Next, bosentan hydrate was directly administered to A/H5N1-infected chicks to confirm the therapeutic effects on avian flu infections; bosentan hydrate was intra-muscularly injected in the birds at 2 hrs post-viral inoculation. Interestingly, the survival rate of the infected birds was dramatically increased by an injection of bosentan hydrate (Figure 2). In addition, the pathological reactions in the infected lungs in infected chicks were decreased by the injection of bosentan hydrate. The edema, hemorrhage, congestion and mucosal exudation were clearly inhibited in the lesions (Figure 3). These findings were consistent with the results showing that the

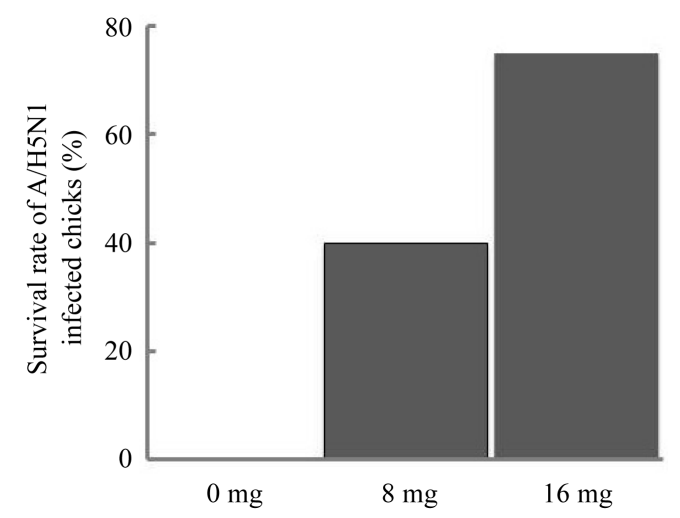

Figure 2. Effects of bosentan hydrate on the survival of A/H5N1-infected chicks. The chicks were intranasally challenged with A/H5N1 virus, and then were administrated bosentan hydrate. The dead chicks were counted five days post-inoculation, and the survival rate was calculated. Without bosentan administration $(0 \mathrm{mg})$, all of the infected birds died within five days. However, the number of survivors was dramatically increased by treatment with $8 \mathrm{mg}$, and was further increased by treatment with $16 \mathrm{mg}$, of bosentan hydrate. Accordingly, the death of the A/H5N1-infected chicks was inhibited by the administration of a high dose of bosentan hydrate.

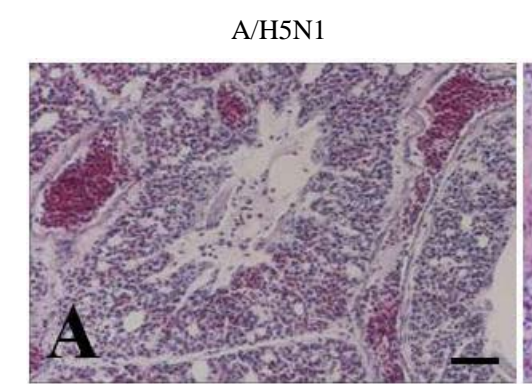

A/H5N1 + bosentan hydrate

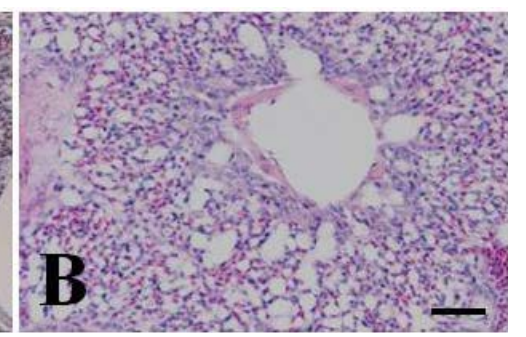

Figure 3. Pulmonary histopathology of A/H5N1-infected chickens after the administration of bosentan hydrate. The sections of A/H5N1-infected chick lung at five days postinoculation with or without bosentan administration were cut and stained with $\mathrm{H} \& \mathrm{E}$. Severe heterophilic infiltration, hemorrhage, edema and mucosal exudation were seen in the interstitium and parabronchial cavities in the lungs from A/H5N1-infected chickens at five days post-infection (A). The congestion was also seen in the affected lungs, whereas pathological lesions were scarcely found in the infected lungs after bosentan injection (B). Bars, $200 \mu \mathrm{m}$. 
mortality of A/H5N1 chicks was decreased by bosentan administration. In non-infected chicks administrated with higher volume of bosentan hydrate, clinical symptoms and histopathological lesions were not observed; bosentan hydrate was safety in chicks in this study. Accordingly, bosentan hydrate could rescue a considerable number of birds from death following A/H5N1 infection.

\subsection{Distribution of Viral Antigens and Endothelin-1 in A/H5N1 Infected Chick Lungs}

Immunofluorescence staining revealed that endothelin-1 was scarcely found in the normal chick lung, whereas enhanced expression of endothelin-1 was seen in the A/H5N1 infected lungs; the specific immunofluorescence was detected in the respiratory endothelial cells and/or infiltrating cells (probably macrophages) in inflammatory lesions (Figure 4). The viral antigens were found in the pulmonary tissues of infected chicks at five days postinoculation. No obvious differences were found in the viral distribution or endothelin-1 expression among A/H5N1-infected birds with or without the administration of bosentan hydrate. This indicated that bosentan hydrate altered neither the endothelin-1 expression nor the viral localization.

\section{Discussion}

The mechanism underlying the sudden death induced by A/H5N1 virus infections remains to be clarified in poultry and mammals [9] [14]. However, the present study demonstrated that endothelin-1 and its receptor might play a role in the sudden death in A/H5N1-infected chickens. The endothelin expression in endothelial or infiltrating cells and the expression of the endothelin receptor are mainly detected in the smooth muscle cells of blood vessels. The interactions of endothelin-1 with its receptor cause vascular contraction under both physiological and pathological situations. The present study strongly suggested that the abnormal vascular contraction induced by endothelin-receptor interactions caused the hemorrhage and congestion, which may have induced the ischemia or multiple organ failure in infected birds, and finally led to sudden death.

Multiple organ failure induced by a cytokine storm is hypothesized to be the main cause of mortality in human cases of A/H5N1 infections, because the secretion of various cytokines is markedly elevated during viral infection [12]. Proinflammatory cytokines, including TNF- $\alpha$, IL-6 and CC chemokine ligand 2, are highly produced in humans and mice during the early stages of infection by highly pathogenic avian flu. However, inhibition of the cytokine response by steroids does not protect animals from death due to highly pathogenic A/H5N1 influenza infection [14]. Interestingly, in this study, a real-time PCR analysis showed that the mRNA level of endothelin-1 was significantly higher in the A/H5N1 infected chick lungs than that in the normal lungs. It has
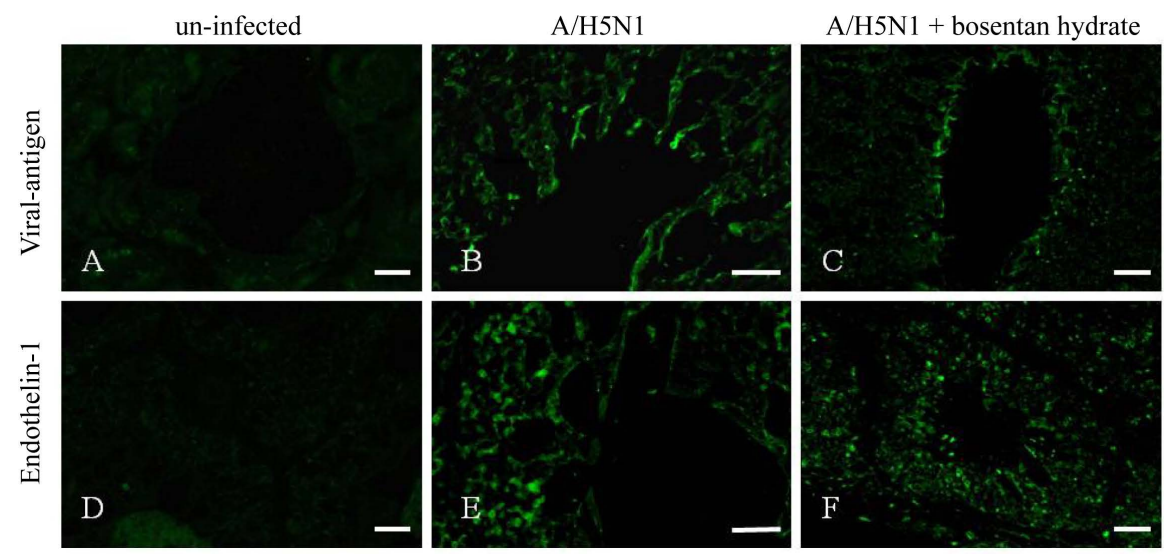

Figure 4. The expression of viral antigens and endothelin-1 in the A/H5N1-infected lungs after the administration of bosentan hydrate. Viral antigens were not found in the uninfected lungs (A), but were observed in A/H5N1 virus-infected lungs (B). The viral antigens were also detected even in the lungs of A/H5N1-infected chicks that were treated with bosentan (C). Endothelin-1 proteins were found only in the uninfected normal lungs (D). In the lungs from chicks with A/H5N1 infection (E) and H5N1 infection treated with bosentan (F), endothelin-1 was widely distributed in various types of cells, mainly in the endothelial and inflammatory cells. Bars, $200 \mu \mathrm{m}$. 
been reported that production of endothelin-1 in vascular endothelial cells and inflammatory cells is increased by various factors including TGF-beta, Interleukin 1, thrombin, TNF-alfa, angiotensin associated with tissue injury and inflammation [29]-[32]. Also inflammatory cells-endothelial contacts and hemodynamic shear stress stimulate endothelin production [33]. In the present study, these factors or cell stress might be increased in injured lungs by A/H5N1 infections that enhance the endothelin-1 levels.

One particularly interesting and potentially important finding of the present study was the fact that bosentan hydrate could rescue the chicks from sudden death following A/H5N1 infections. Bosentan hydrate is an endothelin receptor antagonist which non-selectively binds to both endothelin receptor A and B, and controls various adverse effects, such as vasoconstriction induced by excessive endothelin by inhibiting the interaction of endothelin with its receptors [26] [27]. In this study, bosentan hydrate might have blocked the endothelin-1-induced abnormal vasoconstriction and subsequent hemorrhage, edema and congestion in infected lungs, which all lead to systemic ischemia or acute respiratory distress syndrome.

In preliminary studies and sporadic chicken cases of A/H5N1 infections, micro-hemorrhage and subsequent colliquative necrosis were frequently observed in dead birds, especially in the central nervous system. Therefore, abnormal vasoconstriction by the endothelin-endothelin receptor interactions might occur systemically. Studies are currently underway to elucidate the expression patterns of these molecules in other organs of infected chickens, as well as in the lungs.

This study revealed the therapeutic effects of an endothelin receptor antagonist, bosentan hydrate, on H5N1 infections; a single injection of this drug into the muscle rescued infected chicks from death. More detailed examinations, including different challenge routes, the dose-response relationship and serum level $\left(\mathrm{C}_{\max }\right.$ and halflife) of chemical are underway. In addition, the effects of bosentan should be evaluated for other strains of avian influenza viruses.

Anti-viral drugs have been employed to treat influenza patients [34]. Most of them target NA antigens on the viral surface, for example, oseltamivir and zanamivir target the NA to inhibit the viral release from primary host cells. The authors strongly believe that inhibiting endothelin's function as a vasoconstrictor by blocking its receptors might rescue populations from death in the event of an A/H5N1 pandemic.

\section{References}

[1] Alexander, D.J. and Brown, I.H. (2000) Recent Zoonoses Caused by Influenza A Viruses. Revue scientifique et technique, 19, 197-225.

[2] Spickler, A.R., Trampel, D.W. and Roth, J.A. (2008) The Onset of Virus Shedding and Clinical Signs in Chickens Infected with High-Pathogenicity and Low-Pathogenicity Avian Influenza Viruses. Avian Pathology, 37, 555-557. http://dx.doi.org/10.1080/03079450802499118

[3] Normile, D. (2005) Infectious Diseases. North Korea Collaborates to Fight Bird Flu. Science, 308, 175. http://dx.doi.org/10.1126/science.308.5719.175a

[4] Leroux-Roels, I., Borkowski, A., Vanwolleghem, T., Dreame, M., Clement, F., Hons, E., Devaster, J.M. and LerouxRoeis, G. (2007) Antigen Sparing and Cross-Reactive Immunity with an Adjuvanted rH5N1 Prototype Pandemic Influenza Vaccine: A Randomized Controlled Trial. The Lancet, 370, 580-589. http://dx.doi.org/10.1016/S0140-6736(07)61297-5

[5] Peiris, J.S.M., Yu, W.C., Leung, C.W., Cheung, C.Y., Ng, W.F., Nicholls, J.M., Ng, T.K., Chan, K.H., Lai, S.T., Lim, W.L., Yuen, K.Y. and Guan, Y. (2004) Re-Emergence of Fatal Human Influenza A Subtype H5N1 Disease. The Lancet, 363, 617-619. http://dx.doi.org/10.1016/S0140-6736(04)15595-5

[6] Beigel, J.H., Farrar, J., Han, A.M., Hayden, F.G., Hyer, R., de Jong M.D., Lochindarat, S., Nguyen, T.K., Nguyen, T.H., Tran, T.H., Nicoll, A., Touch, S. and Yuen, K.Y. (2005) Writing Committee of the World Health Organization (WHO) Consultation on Human Influenza A/H5: Avian Influenza A (H5N1) Infection in Humans. The New England Journal of Medicine, 353, 1374-1385. http://dx.doi.org/10.1056/NEJMra052211

[7] Poland, G.A. (2006) Vaccines against Avian Influenza-A Race against Time. The New England Journal of Medicine, 354, 1411-1413. http://dx.doi.org/10.1056/NEJMe068047

[8] Ungchusak, K., Auewarakul, P., Dowell, S.F., Kitphati, R., Auwanit, W., Puthavathana, P., Uiprasertkul, M., Boonnak, K., Pittayawonganon, C., Cox, N.J., Zaki, S.R., Thawatsupha, P., Chittaganpitch, M., Khontong, R., Simmerman, J.M. and Chunsutthiwat, S. (2005) Probable Person-to-Person Transmission of Avian Influenza A (H5N1). The New England Journal of Medicine, 352, 333-340. http://dx.doi.org/10.1056/NEJMoa044021

[9] Chan, M.C., Cheung, C.Y., Chui, W.H., Tsao, S.W., Nicholls, J.M., Chan, Y.O., Chan, R.W., Long, H.T., Poonm, L.L., Guan, Y. and Peiris, J.S. (2005) Proinflammatory Cytokine Responses Induced by Influenza A (H5N1) Viruses in Pri- 
mary Human Alveolar and Bronchial Epithelial Cells. Respiratory Research, 6, 135. http://dx.doi.org/10.1186/1465-9921-6-135

[10] Shinya, K., Ebina, M., Yamada, S., Ono, M., Kasai, N. and Kawaoka, Y. (2006) Avian Flu: Influenza Virus Receptors in the Human Airway. Nature, 440, 435-436. http://dx.doi.org/10.1038/440435a

[11] Yamada, S., Suzuki, Y., Suzuki, T., Le, M.Q., Nidom, C.A., Sakai-Tagawa, Y., Muramoto, Y., Ito, M., Kiso, M., Horimoto, T., Shinya, K., Sawada, T., Kiso, M., Usui, T., Murata, T., Lin, Y., Ha, A., Haire, L.F., Stevens, D.J., Russell, R.J., Gamblin, S.J., Skehel, J.J. and Kawaoka, Y. (2006) Haemagglutinin Mutations Responsible for the Binding of H5N1 Influenza A Viruses to Human-Type Receptors. Nature, 444, 378-382. http://dx.doi.org/10.1038/nature05264

[12] Cheung, C.Y., Poon, L.L., Lau, A.S., Luk, W., Lau, Y.L., Shortridge, K.F., Gordon, S., Guan, Y. and Peiris, J.S. (2002) Induction of Proinframmatory Cytokines in Human Macrophage by Influenza A (H5N1) Viruses: A Mechanism for the Unusual Severity of Human Disease? The Lancet, 360, 1831-1837. http://dx.doi.org/10.1016/S0140-6736(02)11772-7

[13] de Jong, M.D. (2006) Fetal Outcome of Human Influenza A (H5N1) Is Associated with High Viral Load and Hypercytokinemia. Nature Medicine, 12, 1203-1207. http://dx.doi.org/10.1038/nm1477

[14] Salomon, R., Hoffmann, E. and Webster, R.G. (2007) Inhibition of the Cytokine Response Does Not Protect against Lethal H5N1 Influenza Infection. Proceedings of the National Academy of Sciences of the United States of America, 104, 12479-12481. http://dx.doi.org/10.1073/pnas.0705289104

[15] Szretter, K.J., Gangappa, S., Lu, X., Smith, C.W., Shieh, J., Zaki, S.R., Sambhara, S., Tumpey, T.M. and Katz, J.M. (2007) Role of Hostcytokine Responses in the Pathogenisis of Avian H5N1 Viruses in Mice. Journal of Virology, 81, 2736-2744. http://dx.doi.org/10.1128/JVI.02336-06

[16] Inagami, T., Naruse, M. and Hoover, R. (1995) Endothelium as an Endocrine Organ. Annual Review of Psychology, 57, 171-189. http://dx.doi.org/10.1146/annurev.ph.57.030195.001131

[17] Inoue, A., Yanagisawa, M., Kimura, S., Kasuya, Y., Miyauchi, T., Goto, K. and Masakai, T. (1989) The Human Endothelin Family: Three Structurally and Pharmacologically Distinct Isopeptides Predicted by Three Separate Genes. Proceedings of the National Academy of Sciences of the United States of America, 86, 2863-2867. http://dx.doi.org/10.1073/pnas.86.8.2863

[18] Black, S.M., Kumar, S., Wiseman, D., Ravi, K., Wedgwood, S., Ryzhov, V. and Fineman, J.R. (2007) Pediatric Pulmonary Hypertension: Roles of Endothelin-1 and Nitric Oxide. Clinical Hemorheology and Microcirculation, 37, 111120.

[19] Shimoda, L.A., Sham, J.S., Liu, Q. and Sylvester, J.T. (2002) Acute and Chronic Hypoxic Pulmonary Vasoconstriction: A Central Role for Endothelin-1. Respiratory Physiology \& Neurobiology, 132, 93-106. http://dx.doi.org/10.1016/S1569-9048(02)00052-6

[20] Weigand, L., Sylvester, J.T. and Shimoda, L.A. (2006) Mechanisms of Endothelin-1-Induced Contraction in Pulmonary Arteries from Chronically Hypoxic Rats. American Journal of Physiology, 290, L284-L290.

[21] Sakurai, M., Yanagisawa, Y., Takuwa, H., Miyazaki, S., Kimura, K., Goto, Y. and Masaki, T. (1990) Cloning of a cDNA Encoding a Non-Isopeptides-Selective Subtype of the Endothelin Receptor. Nature, 348, 732-735. http://dx.doi.org/10.1038/348732a0

[22] Carr, M.J., Spalding, L.J., Goldie, R.G. and Henry, P.J. (1998) Distribution of Immunoreactive Endothelin in the Lungs of Mice during Respiratory Viral Infection. European Respiratory Journal, 11, 79-85. http://dx.doi.org/10.1183/09031936.98.11010079

[23] Adachi, K., Handharyani, E., Sari, D.K., Takama, K., Fukuda, K., Endo, I., Yamamoto, R., Sawa, M., Tanaka, M., Konishi, I. and Tsukamoto, Y. (2008) Development of Neutralization Antibodies against Highly Pathogenic H5N1 Avian Influenza Virus Using Ostrich (Struthio camelus) Yolk. Molecular Medicine Reports, 1, 203-209.

[24] Kamiyama, Y., Adachi, K., Handharyani, E., Soejoedono, R.D., Kusano, T., Inai, M., Tsukamoto, M., Kashiwagi, S. and Tsukamoto, Y. (2011) Protection from Avian Influenza H5N1 Virus Infection with Antibody-Impregnated Filters. Virology Journal, 8, 54. http://dx.doi.org/10.1186/1743-422X-8-54

[25] Reed, L.J. and Muench, H. (1938) A Simple Method of Estimating Fifty Percent End-Points. American Journal of Hygiene, 27, 493-497.

[26] Clozel, M., Breu, V., Gray, G.A., Kalina, B., Löffler, B.M., Burri, K., Cassal, J.M., Hirth, G., Müller, M. and Neidhart, W. (1994) Pharmacological Characterization of Bosentan, a New Potent Orally Active Nonpeptide Endothelin Receptor Antagonist. Journal of Pharmacology and Experimental Therapeutics, 270, 228-235.

[27] Seo, B., Oemar, B.S., Siebenmann, R., von Segesser, L. and Lüscher, T.F. (1997) Endothelin Plays a Role in the Maintenance of Blood Pressure in Normotensive Guinea Pigs. Circulation, 89, 1203-1208. http://dx.doi.org/10.1161/01.CIR.89.3.1203

[28] Gomez, A.P., Moreno, M.J., Iglesias, A., Coral, P.X. and Hernandez, A. (2007) Endothelin 1, Its Endothelin Type A Receptor, Connective Tissue Growth Factor, Platelet-Derived Growth Factor and Adrenomedullin Expression in Lungs 
of Pulmonary Hypertensive and Nonhypertensive Chickens. Poultry Science, 86, 909-916. http://dx.doi.org/10.1093/ps/86.5.909

[29] Emori, T., Hirata, Y., Ohta, K., Shichiri, M. and Marumo, F. (1989) Secretory Mechanism of Immunoreactive Endothelin in Cultured Bovine Endothelial Cells. Biochemical and Biophysical Research Communications, 160, 93-100. http://dx.doi.org/10.1016/0006-291X(89)91625-2

[30] Kurihara, H., Yoshizumi, M., Sugiyama, T., Takaku, F., Yanagisawa, M., Masaki, T., Hamaoki, M., Kato, H. and Yazaki, Y. (1989) Transforming Growth Factor-Beta Stimulates the Expression of Endothelin mRNA by Vascular Endothelial Cells. Biochemical and Biophysical Research Communications, 159, 1435-1440. http://dx.doi.org/10.1016/0006-291X(89)92270-5

[31] Yoshizumi, M., Kurihara, H., Morita, T., Yamashita, T., Oh-hashi, Y., Sugiyama, T., Takaku, F., Yanagisawa, M., Masaki, T. and Yazaki, Y. (1990) Interleukin 1 Increases the Production of Endothelin-1 by Cultured Endothelial Cells. Biochemical and Biophysical Research Communications, 166, 324-329. http://dx.doi.org/10.1016/0006-291X(90)91948-R

[32] Maemura, K., Kurihara, H., Morita, T., Oh-hashi, Y. and Yazaki, Y. (1992) Production of Endothelin-1 in Vascular Endothelial Cells Is Regulated by Factors Associated with Vascular Injury. Gerontology, 38, 29-35. http://dx.doi.org/10.1159/000213360

[33] Yoshizumi, M., Kurihara, H., Sugiyama, T., Takaku, F., Yanagisawa, M., Masaki, T. and Yazaki, Y. (1989) Hemodynamic Shear Stress Stimulates Endothelin Production by Cultured Endothelial Cells. Biochemical and Biophysical Research Communications, 161, 859-864. http://dx.doi.org/10.1016/0006-291X(89)92679-X

[34] Bridges, C.B., Kuehnert, M.J. and Hall, C.B. (2003) Transmission of Influenza: Implications for Control in Health Care Settings. Clinical Infectious Diseases, 37, 1094-1101. http://dx.doi.org/10.1086/378292 
Scientific Research Publishing (SCIRP) is one of the largest Open Access journal publishers. It is currently publishing more than 200 open access, online, peer-reviewed journals covering a wide range of academic disciplines. SCIRP serves the worldwide academic communities and contributes to the progress and application of science with its publication.

Other selected journals from SCIRP are listed as below. Submit your manuscript to us via either submit@scirp.org or Online Submission Portal.
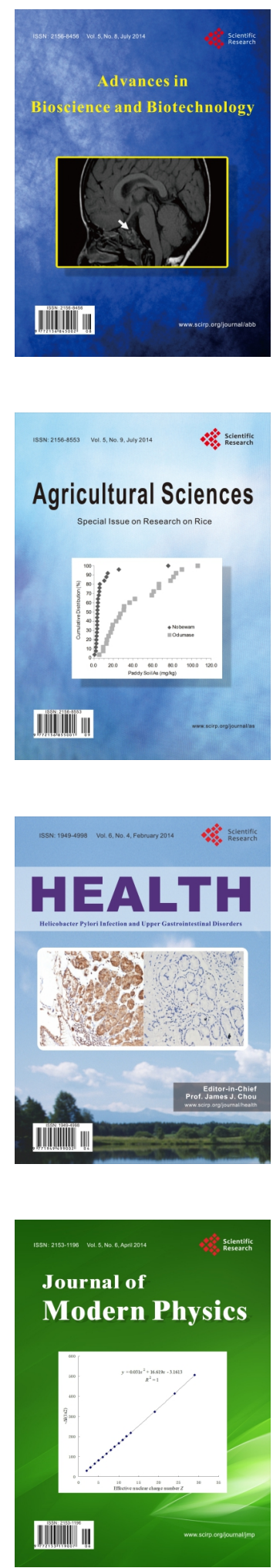
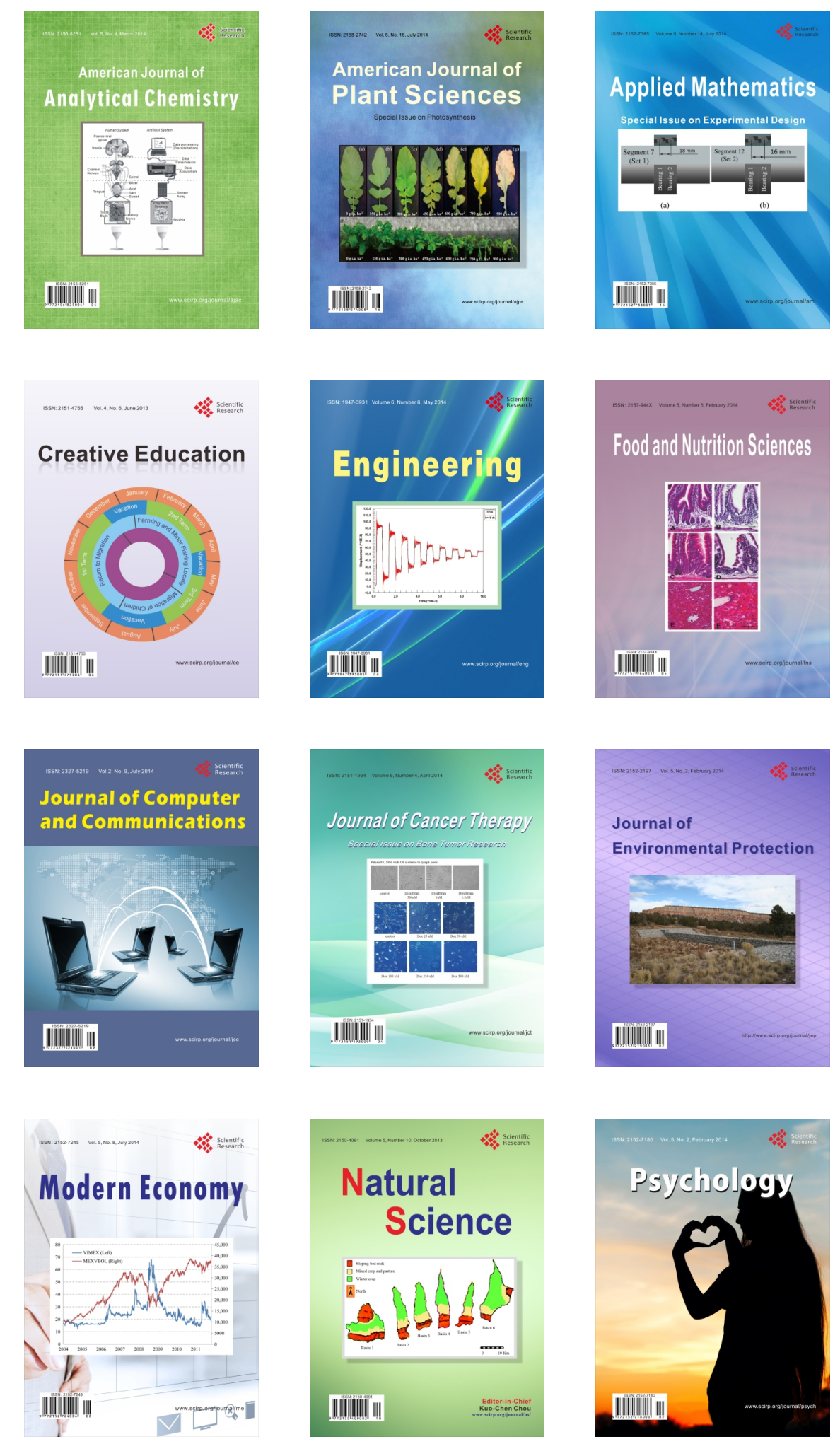